\title{
Evaluasi Kualitas Pelayanan Jasa Kepariwisataan Dengan Metode SERVQUAL dan QFD
}

\author{
Didi Junaedi \\ Program Studi Teknik Industri Universitas Mercu Buana Jakarta \\ Email: didi.junaedi79@gmail.com
}

\begin{abstract}
Abstrak
Kasepuhan Palace Cirebon tourism services participate to build the economy of the country, especially the city of Cirebon. Therefore, in order to further increase the number of visits, the service quality should be improved. Using SERVQUAL method, can know the perception of service quality kasepuhan palace Cirebon. Measuring the quality of services performed on five dimensions that is tangible, responsiveness, assurance, reliability, and empathy. The results of this study showed that all of the dimensions are still not as expected visitors. Improvement starting from the dimensions of responsiveness that has the smallest SERVQUAL score. QFD can be analyzed using improvement priorities according to customer needs. The most important priority that needs to be adequate hygiene team, demolition charges, as well as the renovation and restoration. Overall it can be proposed for improving services such as: improvement of operational systems, improvements and additions to the facility, the addition of human resources and training. Limitations in this study is only the first phase $H O Q$.
\end{abstract}

Keywords: Quality, SERVQUAL, QFD, Improvement, $H O Q$

\section{PENDAHULUAN}

Industri pariwisata sebagai salah satu industri jasa ikut membantu meningkatkan perekonomian negara seiring dengan industri lainnya seperti pertanian, pertambangan dan manufaktur. Data kunjungan pada tahun 2012 sebanyak 89.173 sedangkan pada tahun 2013 mengalami penurunan menjadi 87.226 wisatawan. Tahun 2014 angka kunjungan naik yaitu sebanyak 88.789 wisatawan tetapi angka ini masih dibawah rekor kunjungan tahun 2012. Setiap tahunnya Keraton Kasepuhan hanya mengandalkan event tertentu saja seperti muludan atau lebaran untuk menarik banyak pengunjung. Wisatawan di hari biasa juga perlu ditingkatkan oleh karena itu perlu perbaikan secara menyeluruh dan profesional sehingga mampu menarik wisatawan.

Mengukur kualitas suatu industri jasa bisa dengan menggunakan metode SERVQUAL, Menurut Parasuraman, Zeithaml dan Berry (1988), ada 5 dimensi yang diukur yaitu: tangible (wujud), reability (kehandalan), responsiveness (cepat tanggap), assurance (keyakinan atas pelayanan), dan empathy (kepedulian). Penelitian mengenai jasa pariwisata sebelumnya yang merujuk kepada model SERVQUAL pernah dilakukan oleh Tan dan Pawitra (2003), dengan menggunakan metode integrasi SERVQUAL, Model Kano dan Quality Function Deployment (QFD) meneliti mengenai image dan kepuasan pariwisata Singapura menurut perspektif turis Indonesia. Shi (2008), melakukan penelitian kepuasan pengunjung di museum prasejarah Taiwan. Markovic et al.(2013), meneliti kepuasan pengunjung di museum Kroasia. Adapula penelitian oleh Triwibowo dkk. (2014), mengenai pelayanan jasa ekowisata di kawasan wisata kawah putih Jawa Barat.

Tujuan dari penelitian ini adalah sebagai berikut:

1. Mengetahui atribut harapan pengunjung mengenai kualitas pelayanan Keraton Kasepuhan Cirebon.

2. Mengetahui Kesenjangan (gap) kualitas pelayanan yang dirasakan dengan yang diharapkan pada Keraton Kasepuhan Cirebon.

3. Mengetahui cara perbaikan kualitas pelayanan di Keraton Kasepuhan Cirebon yang sesuai dengan harapan pengunjung. 


\section{KAJIAN PUSTAKA}

\section{Service Quality}

Parasuraman et al. (1990) menyatakan bahwa kualitas jasa adalah perbandingan antara harapan dan persepsi konsumen terhadap kinerja jasa yang mereka terima, apabila pelayanan yang diterima atau dirasakan sesuai dengan harapan, maka kualitas pelayanan dipersepsikan baik dan memuaskan. Model SERVQUAL adalah alat yang digunakan untuk mengukur kualitas jasa (Parasuraman et al., 1990). Cara ini mulai dikembangkan pada tahun 1980-an oleh Zeithaml, Parasuraman \& Berry, dan telah digunakan dalam mengukur berbagai kualitas jasa.

Pengukuran kualitas dengan metode ini terdiri dari 5 dimensi kualitas jasa yaitu tangibles, reliability, responsiveness, assurance, dan empathy dimana setiap jasa yang ditawarkan memiliki beberapa aspek yangdapat dipergunakan untuk mengetahui tingkat kualitasnya. Nilai servqual merupakan besarnya gap 5 yang diperoleh dengan mengurangi nilai persepsi dan nilai harapan.

Parasuraman et al. (1990) mengidentifikasikan lima kesenjangan (gap) yang menyebabkan kegagalan penyampaian jasa, yaitu:

1. Gap 1 adalah kesenjangan antara harapan konsumen dengan persepsi manajemen terhadap harapan konsumen. Faktor penyebabnya adalah:
a. Ketidaksesuaian penggunaan penelitian pemasaran
b. Penelitian pemasaran yang tidak efektif
c. Buruknya upward communication

2. Gap 2 adalah kesenjangan antara persepsi manajemen dengan spesifikasi kualitas jasa dimana spesifikasi kualitas jasa tidak mewakili harapan konsumen. Faktor penyebabnya adalah:

a. Tidak sesuainya komitmen manajemen dengan kualitas jasa

b. Tidak adanya proses formal dalam menentukan tujuan dari kualitas jasa

c. Tidak sesuainya standar pekerjaan

3. Gap 3 adalah kesenjangan antara spesifikasi kualitas jasa dengan penyampaianjasa dimana spesifikasi kualitas jasa tidak hanya mewakili harapan konsumen tetapi juga harus didukung oleh sumber daya yang sesuai dan mencukupi.

Faktor penyebabnya adalah:

a. Tim kerja yang buruk

b. Teknologi yang rendah

c. Karyawan yang tidak berkompeten

d. Evaluasi yang tidak sesuai

4. Gap 4 adalah kesenjangan antara penyampaian jasa dengan komunikasieksternal. Faktor penyebabnya adalah:

a. Kurangnya komunikasi antara salesman dengan bagian operasional

b. Kurangnya komunikasi antara bagian periklanan dengan bagian operasional

c. Perbedaan kebijakan dan prosedur antara cabang dan departemen

5. Gap 5 adalah kesenjangan antara jasa yang diterima dengan jasa yang diharapkan. Jasa yang diharapkan dipengaruhi oleh komunikasi dari mulut kemulut, kebutuhan pribadi, pengalaman masa lalu, dan komunikasi eksternal kepada pelanggan.

Pada penelitian ini yang akan dibahas yaitu gap 5 yaitu kesenjangan jasa yang diterima dengan jasa yang diharapkan karena gap 5 menunjukkan kualitas pelayanan yang dirasakanpelanggan.

Konsep SERVQUAL digunakan untuk menghitung gap antara persepsi dan harapan yang diinginkan pelanggan yang dapat dirumuskan dalam persamaan berikut:

$$
\mathrm{Q}=\mathrm{P}-\mathrm{E} \text {. }
$$

Keterangan: 
$\mathrm{Q}=$ Kualitas pelayanan (quality of service)

$\mathrm{P}=$ Perceived service (persepsi yang dirasakan pelanggan); $\mathrm{E}=$ Expected service (harapan pelanggan terhadap layanan).

\section{Kepuasan Pelanggan}

Konsep kepuasan pelanggan pertama kali dikembangkan pada tahun 1970-an oleh Philip Kotler. Menurut Kotler (2000) kepuasan pelanggan adalah tingkat perasaan seseorang yang muncul setelah membandingkan antara persepsi terhadap kinerja (atau hasil) suatu produk dengan harapanharapannya. Menurut Yuri dan Nurcahyo (2013), kepuasan pelanggan adalah keadaan ketika kebutuhan, keinginan, dan harapan pelanggan dapat terpenuhi melalui produk atau jasa yang dikonsumsi atau dibutuhkannya. Sedangkan untuk mengukur tingkat kepuasan pelanggan dapat dilakukan dengan beberapa cara antara lain melalui sistem keluhan dan saran, survei kepuasan pelanggan, ghost shopping, dan analisis lost customer.

\section{Quality Function Deployment (QFD)}

Quality Function Deployment (QFD) pertama kali dikembangkan oleh Yoji Akao pada tahun 1972 di Jepang. QFD disebut juga dalam bahasa jepang yaitu hin shitsu kino ten kai. Dimana hin shitsu berarti kualitas atau fitur atau atribut, kino berarti fungsi atau mekanisasi, dan ten kai berarti penyebaran, difusi, pengembangan atau evolusi.

Menurut Akao (1990) dalam Tan dan Pawitra (2001), mendefinisikan QFD sebagai sistem untuk menerjemahkan persyaratan pelanggan ke dalam persyaratan teknis yang sesuai pada setiap tahap siklus hidup produk dari konsep produk ke penjualan dan ke pelayanan. Sedangkan menurut Cohen (1995), mendefinisikan QFD sebagai metode perencanaan dan pengembangan produk yang terstruktur untuk menetapkan spesifikasi kebutuhan dan keinginan konsumen, serta mengevaluasi kapabilitas suatu produk atau jasa secara sistematis dalam memenuhi kebutuhan dan keinginan konsumen.

\section{METODOLOGI PENELITIAN}

Metode penelitian yang digunakan dalam penelitian ini yaitu metode kuantitatif. Sedangkan jenis atau tujuan penelitian yaitu eksploratif deskriptif dimana penelitian bertujuan untuk mengembangkan gambaran dasar mengenai pengukuran kualitas jasa wisata serta mendeskripsikan atas informasi yang menunjukkan keadaan saat ini.

Dalam penelitian ini data yang dikumpulkan dari responden merupakan suatu persepsi, dengan menggunakan skala Likert, jawaban atas pernyataan yang disampaikan dalam kuesioner berupa skala Likert yang telah dimodifikasi terdiri dari 2 bagian, jawaban atas harapan dan persepsi. Skala penilaian atau bobot dari 1 sampai 5 . Untuk jawaban tingkat kepentingan dari sangat tidak penting (bobot 1), tidak penting (bobot 2), cukup penting (bobot 3), penting (bobot 4) dan sangat penting (bobot 5). Sedangkan tingkat persepsi sangat tidak baik (bobot 1), tidak baik (bobot 2), cukup baik (bobot 3), baik (bobot 4) dan sangat baik (bobot 5).

Kuesioner disebarkan kepada 200 responden dan berdasarkan hasil perhitungan, diketahui jumlah sampel minimal yang diambil sebanyak 191 sampel. Dari 200 kuesioner yang disebar dalam penelitian ini, kuesioner yang terisi dengan baik sebanyak 193 kuesioner sedangkan 7 kuesioner tidak terisi lengkap. Sehingga yang dapat digunakan sebagai data primer yaitu sebanyak 193 kuesioner atau sampel karena jumlah tersebut sudah melebihi jumlah sampel minimal.

\section{HASIL DAN PEMBAHASAN}

\section{Menentukan Gap antara Persepsi dan Harapan}

Gap yang diukur dalam penelitian ini adalah gap 5 yaitu gap pelanggan (customer gap). Gap ini mengukur kesenjangan pelayanan yang dirasakan (perceived service) dengan pelayanan yang diharapkan (expected service) oleh pelanggan. 
Pada Tabel 1 skor SERVQUAL masing-masing item menunjukan angka negatif semua hal ini menandakan bahwa persepsi pengunjung keraton terhadap pelayanan yang diterima belum sesuai dengan harapan.

Contoh perhitungan skor SERVQUAL untuk item 1 dengan menggunakan rumus yang telah dijelaskan diatas sebagai berikut:

Skor SERVQUAL $\quad=\mathrm{P}$ (nilai persepsi) $-\mathrm{E}$ (nilai harapan)

$$
=3.834-4.171
$$$$
=-0.337
$$

Tabel 1. Hasil Perhitungan Gap Antara Persepsi dengan Harapan

\begin{tabular}{|c|c|c|c|c|c|c|c|c|}
\hline \multirow[b]{2}{*}{ Dimensi } & \multirow{2}{*}{$\begin{array}{c}\text { No } \\
\text { Atribut }\end{array}$} & \multicolumn{3}{|c|}{ Persepsi } & \multicolumn{3}{|c|}{ Harapan } & \multirow[b]{2}{*}{ GAP } \\
\hline & & $\begin{array}{l}\text { Total } \\
\text { Skor }\end{array}$ & $\begin{array}{l}\text { Rata- } \\
\text { Rata }\end{array}$ & $\%$ & $\begin{array}{l}\text { Total } \\
\text { Skor }\end{array}$ & $\begin{array}{l}\text { Rata- } \\
\text { Rata }\end{array}$ & $\%$ & \\
\hline \multirow{11}{*}{ 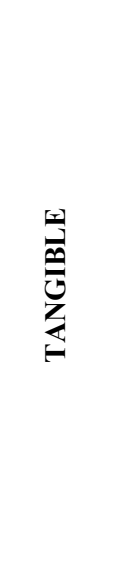 } & 1 & 740 & 3.834 & $77 \%$ & 805 & 4.171 & $83 \%$ & -0.337 \\
\hline & 2 & 704 & 3.648 & $73 \%$ & 806 & 4.176 & $84 \%$ & -0.528 \\
\hline & 3 & 630 & 3.264 & $65 \%$ & 849 & 4.399 & $88 \%$ & -1.135 \\
\hline & 4 & 640 & 3.316 & $66 \%$ & 811 & 4.202 & $84 \%$ & -0.886 \\
\hline & 5 & 632 & 3.275 & $65 \%$ & 838 & 4.342 & $87 \%$ & -1.067 \\
\hline & 6 & 636 & 3.295 & $66 \%$ & 861 & 4.461 & $89 \%$ & -1.166 \\
\hline & 7 & 709 & 3.674 & $73 \%$ & 869 & 4.503 & $90 \%$ & -0.829 \\
\hline & 8 & 665 & 3.446 & $69 \%$ & 839 & 4.347 & $87 \%$ & -0.902 \\
\hline & 9 & 699 & 3.622 & $72 \%$ & 831 & 4.306 & $86 \%$ & -0.684 \\
\hline & 10 & 688 & 3.565 & $71 \%$ & 825 & 4.275 & $85 \%$ & -0.710 \\
\hline & 11 & 570 & 2.953 & $59 \%$ & 716 & 3.710 & $74 \%$ & -0.756 \\
\hline \multirow{3}{*}{ 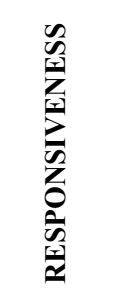 } & 12 & 618 & 3.202 & $64 \%$ & 841 & 4.358 & $87 \%$ & -1.155 \\
\hline & 13 & 647 & 3.352 & $67 \%$ & 817 & 4.233 & $85 \%$ & -0.881 \\
\hline & 14 & 648 & 3.358 & $67 \%$ & 830 & 4.301 & $86 \%$ & -0.943 \\
\hline \multirow{2}{*}{ 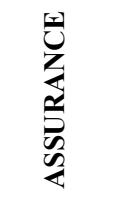 } & 15 & 678 & 3.513 & $70 \%$ & 863 & 4.472 & $89 \%$ & -0.959 \\
\hline & 16 & 672 & 3.482 & $70 \%$ & 861 & 4.461 & $89 \%$ & -0.979 \\
\hline \multirow{5}{*}{ 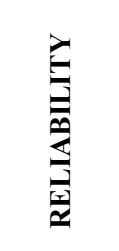 } & 17 & 754 & 3.907 & $78 \%$ & 859 & 4.451 & $89 \%$ & -0.544 \\
\hline & 18 & 739 & 3.829 & $77 \%$ & 836 & 4.332 & $87 \%$ & -0.503 \\
\hline & 19 & 743 & 3.850 & $77 \%$ & 872 & 4.518 & $90 \%$ & -0.668 \\
\hline & 20 & 708 & 3.668 & $73 \%$ & 820 & 4.249 & $85 \%$ & -0.580 \\
\hline & 21 & 594 & 3.078 & $62 \%$ & 806 & 4.176 & $84 \%$ & -1.098 \\
\hline \multirow{4}{*}{ 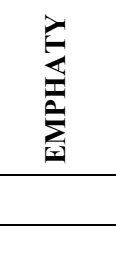 } & 22 & 706 & 3.658 & $73 \%$ & 826 & 4.280 & $86 \%$ & -0.622 \\
\hline & 23 & 759 & 3.933 & $79 \%$ & 847 & 4.389 & $88 \%$ & -0.456 \\
\hline & Jumlah & & 80.720 & & & 99.109 & & -18.389 \\
\hline & Rata-rata & & 3.510 & & & 4.309 & & -0.800 \\
\hline
\end{tabular}


Dengan cara seperti perhitungan diatas, dapat dihitung skor SERVQUAL pada masing-masing dimensi yaitu dari nilai rata-ratanya. Untuk perhitungan dimensi tangibles terdiri dari 11 item dapat dihitung skor SERVQUAL seperti dibawah ini:

Skor SERVQUAL $=($ Total rata-rata persepsi tiap item : 11$)-($ Total rata-rata harapan tiap item :

$$
\text { 11) }
$$

Skor SERVQUAL $=3.445-4.263$

$$
=-0.818
$$

Skor SERVQUAL 5 dimensi ditunjukan pada Tabel 2.

Tabel 2. Hasil Perhitungan Gap Tiap Dimensi

\begin{tabular}{cccc}
\hline Dimensi & $\begin{array}{c}\text { Item } \\
\text { Pernyataan }\end{array}$ & $\begin{array}{c}\text { Skor } \\
\text { SERVQUAL }\end{array}$ & $\begin{array}{c}\text { Ranking } \\
\text { Gap }\end{array}$ \\
\hline Tangible (Penampilan) & $1-11$ & -0.818 & 3 \\
Responsiveness (Cepat Tanggap) & $12-14$ & -0.993 & 1 \\
Assurance (Kompetensi) & $15-16$ & -0.969 & 2 \\
Reliability (Kehandalan) & $17-21$ & -0.679 & 4 \\
Emphaty (Empati) & $22-23$ & -0.539 & 5 \\
\hline
\end{tabular}

Pada Tabel 2 dari skor 5 dimensi SERVQUAL dapat dianalisa bahwa dimensi yang paling besar gapnya adalah dimensi Responsiveness (Cepat Tanggap) dengan skor -0.993. Selanjutnya urutan kedua yaitu dimensi Assurance (Kompetensi) dengan skor -0.969. Ketiga, yaitu dimensi Tangible (Penampilan) dengan skor -0.818. Keempat, yaitu dimensi Reliability (Kehandalan) dengan skor 0.679. Dimensi kelima yaitu Emphaty (Empati) dengan skor -0.539.

Sedangkan untuk menghitung skor SERVQUAL tunggal dapat diperoleh dari selisih antara ratarata total persepsi dengan rata-rata total harapan. Hasilnya seperti pada tabel 4.9, skor SERVQUAL sebesar -0.800 .

\section{Analisa House of Quality}

Salah satu hal penting dalam QFD adalah House of Quality (HOQ). Tahap-tahap dalam pembuatan HOQ adalah:

a. Membuat matriks Voice of Customer (Whats)

b. Menentukan prioritas yang dibutuhkan konsumen

c. Membuat matriks respon teknis (Hows)

d. Membuat korelasi antara whats dan hows

e. Membuat korelasi antar respon teknis

f. Menentukan prioritas teknis.

\section{a. Kebutuhan Pelanggan (customer need)}

Hasil SERVQUAL yang memiliki nilai negatif dimasukkan dalam matriks house of quality sebagai kebutuhan pelanggan (customer need) seperti yang ditunjukkan pada Tabel 3 dimasukkan kedalam house of quality pada bagian kiri Gambar 1.

\section{b. Prioritas yang Dibutuhkan Konsumen}

Prioritas atau bobot dari kebutuhan konsumen atau pelanggan terdiri dari nilai tingkat kepentingan dan bobot relative (relative weight).

\section{$>\quad$ Tingkat Kepentingan atau Importance level}

Setelah dilakukan analisis Gap 5 (persepsi - harapan) berdasarkan dimensi Servqual, maka langkah selanjutnya adalah melakukan interpolasi untuk mengkonversikan tingkat persepsi dan tingkat harapan pelanggan menjadi tingkat kepentingan pelanggan dengan cara interpolasi (Halim dkk., 2013). Contoh perhitungan pada atribut 1 sebagai berikut:

$$
\begin{aligned}
\text { Tingkat Kepentingan } & =1+\frac{G A P-4}{((-4)-4)} x(5-1) \\
& =1+\frac{0.33-4}{((-4)-4)} x(4)=3.17
\end{aligned}
$$


Hasil konversi Gap 5 menjadi tingkat kepentingan pelanggan atau importance dapat dilihat pada Tabel 4.

\section{Nilai Relative Weight}

Untuk menentukan nilai relative weight dengan cara membagi antara tingkat kepentingan dengan total nilai tingkat kepentingan semua atribut dari 1 s.d 23, hasilnya dapat dilihat pada Tabel 5.

Tabel 3. Kebutuhan Pelanggan

\begin{tabular}{cl}
\hline No & \multicolumn{1}{c}{ Kebutuhan Pelanggan } \\
\hline 1 & Penampilan pemandu wisata (guide) dan staf menarik \\
2 & Papan petunjuk tempat atau arah dapat terlihat jelas \\
3 & Kebersihan lingkungan (indoor \& outdoor) \\
4 & Tempat parkir yang memadai \\
5 & Tersedia sarana kebersihan \\
6 & Toilet yang bersih dan nyaman \\
7 & Bangunan atau benda-benda bersejarah terawat dan terjaga keotentikannya \\
8 & Taman terawat dan asri \\
9 & Koleksi museum yang bervariasi \\
10 & Penataan benda-benda sejarah \\
11 & Tersedia toko souvenir \\
12 & Kesiagaan petugas kebersihan \\
13 & Kesiagaan petugas parkir \\
14 & Kesiagaan petugas keamanan \\
15 & Keamanan \& kenyamanan saat di sekitar area wisata \\
16 & Keamanan parkir kendaraan \\
17 & Kemampuan pemandu wisata menyampaikan informasi dengan baik \\
18 & Layanan pembelian tiket masuk yang mudah dan cepat \\
19 & Sebagai sarana edukasi tentang sejarah dan budaya yang menarik \\
20 & Harga tiket masuk yang terjangkau \\
21 & Penataan pedagang kaki lima \\
22 & Warga lingkungan sekitar ramah dan sopan \\
23 & Staf dan pemandu menyambut pengunjung dengan ramah \\
\hline &
\end{tabular}

Tabel 4. Tingkat Kepentingan Pelanggan (weight/importance)

\begin{tabular}{clc}
\hline No & \multicolumn{1}{c}{ Kebutuhan Pelanggan } & $\begin{array}{c}\text { Weight/ } \\
\text { Importance }\end{array}$ \\
\hline 1 & Penampilan pemandu wisata (guide) dan staf menarik & 3.17 \\
2 & Papan petunjuk tempat atau arah dapat terlihat jelas & 3.26 \\
3 & Kebersihan lingkungan (indoor \& outdoor) & 3.57 \\
4 & Tempat parkir yang memadai & 3.44 \\
5 & Tersedia sarana kebersihan & 3.53 \\
6 & Toilet yang bersih dan nyaman & 3.58 \\
7 & Bangunan atau benda-benda bersejarah terawat dan & 3.41 \\
8 & terjaga keotentikannya & 3.45 \\
9 & Kaman terawat dan asri & 3.34 \\
10 & Penataan benda-benda sejarah & 3.35 \\
11 & Tersedia toko souvenir & 3.38 \\
12 & Kesiagaan petugas kebersihan & 3.58 \\
13 & Kesiagaan petugas parkir & 3.44 \\
14 & Kesiagaan petugas keamanan & 3.47 \\
15 & Keamanan \& kenyamanan saat di sekitar area wisata & 3.48 \\
16 & Keamanan parkir kendaraan & 3.49 \\
17 & Kemampuan pemandu wisata menyampaikan informasi & 3.27 \\
18 & dengan baik & Layanan pembelian tiket masuk yang mudah dan cepat \\
19 & Sebagai sarana edukasi tentang sejarah dan budaya yang & 3.25 \\
20 & menarik & 3.33 \\
21 & Penataan pedagang kaki lima & 3.29 \\
22 & Warga lingkungan sekitar ramah dan sopan & 3.55 \\
23 & Staf dan pemandu menyambut pengunjung dengan & 3.31 \\
\hline & ramah & 3.23 \\
\hline
\end{tabular}


Tabel 5. Menentukan relative weight Pada Matriks Customer Need

\begin{tabular}{|c|c|c|c|}
\hline No & Kebutuhan Pelanggan & $\begin{array}{c}\text { Weight/ } \\
\text { Importance }\end{array}$ & $\begin{array}{c}\text { Relative } \\
\text { Weight }\end{array}$ \\
\hline 1 & Penampilan pemandu wisata (guide) dan staf menarik & 3.17 & 4.05 \\
\hline 2 & Papan petunjuk tempat atau arah dapat terlihat jelas & 3.26 & 4.17 \\
\hline 3 & Kebersihan lingkungan (indoor \& outdoor) & 3.57 & 4.56 \\
\hline 4 & Tempat parkir yang memadai & 3.44 & 4.40 \\
\hline 5 & Tersedia sarana kebersihan & 3.53 & 4.52 \\
\hline 6 & Toilet yang bersih dan nyaman & 3.58 & 4.58 \\
\hline 7 & Bangunan atau benda-benda bersejarah terawat dan terjaga keotentikannya & 3.41 & 4.37 \\
\hline 8 & Taman terawat dan asri & 3.45 & 4.41 \\
\hline 9 & Koleksi museum yang bervariasi & 3.34 & 4.27 \\
\hline 10 & Penataan benda-benda sejarah & 3.35 & 4.29 \\
\hline 11 & Tersedia toko souvenir & 3.38 & 4.32 \\
\hline 12 & Kesiagaan petugas kebersihan & 3.58 & 4.58 \\
\hline 13 & Kesiagaan petugas parkir & 3.44 & 4.40 \\
\hline 14 & Kesiagaan petugas keamanan & 3.47 & 4.44 \\
\hline 15 & Keamanan \& kenyamanan saat di sekitar area wisata & 3.48 & 4.45 \\
\hline 16 & Keamanan parkir kendaraan & 3.49 & 4.46 \\
\hline 17 & Kemampuan pemandu wisata menyampaikan informasi dengan baik & 3.27 & 4.18 \\
\hline 18 & Layanan pembelian tiket masuk yang mudah dan cepat & 3.25 & 4.16 \\
\hline 19 & Sebagai sarana edukasi tentang sejarah dan budaya yang menarik & 3.33 & 4.26 \\
\hline 20 & Harga tiket masuk yang terjangkau & 3.29 & 4.21 \\
\hline 21 & Penataan pedagang kaki lima & 3.55 & 4.54 \\
\hline 22 & Warga lingkungan sekitar ramah dan sopan & 3.31 & 4.23 \\
\hline 23 & Staf dan pemandu menyambut pengunjung dengan ramah & 3.23 & 4.13 \\
\hline \multicolumn{2}{|r|}{ Jumlah } & 78.19 & 100 \\
\hline
\end{tabular}

\section{c. Respon Teknik}

Respon teknik diperoleh dari diskusi bersama pihak manajemen Keraton Kasepuhan Cirebon, dengan hasil rumusan seperti yang tampak pada Tabel 6.

Tabel 6. Respon Teknik

\begin{tabular}{clll}
\hline No & \multicolumn{1}{c}{ Respon Teknik } & No & \multicolumn{1}{c}{ Respon Teknik } \\
\hline 1 & Penampilan dan pakaian rapih & 13 & Kesiapan petugas parkir \\
2 & Warna dan tulisan di papan petunjuk jelas & 14 & Tenaga keamanan yang memadai \\
3 & Area parkir luas & 15 & Penertiban (pungli) \\
4 & Tersedia tempat sampah & 16 & Tersedia kamera pengawas (CCTV) \\
5 & Tersedia peralatan kebersihan & 17 & Penguasaan materi presentasi (sejarah Keraton) \\
6 & Renovasi \& restorasi & 18 & Komunikasi dengan bahasa yang baik dan mudah \\
7 & Dukungan pemerintah & 19 & Kesigapan petugas tiket dalam melayani \\
8 & Tanaman terawat dan rumput dipotong rapi & 20 & Komputer dan printer cetak tiket terawat dengan baik \\
9 & Kelengkapan koleksi museum & 21 & Pemberian diskon \\
10 & Benda-benda museum tertata dengan baik & 22 & Keteraturan pedagang kaki lima \\
11 & Tersedia toko souvenir resmi & 23 & Sosialisasi dan pendekatan dengan warga lingkungan \\
& & 24 & Pekitar \\
12 & Tenaga kebersihan yang memadai & $24 a$ lainnya \\
\hline
\end{tabular}




\section{d. Hubungan Antara Kebutuhan Pelanggan (Whats) dengan Respon Teknik (Hows)}

Setelah memperoleh respon teknik, maka dapat dihubungkan dengan customer need seperti pada bagian tengah Gambar 1 House of Quality dari pelayanan obyek wisata Keraton Kasepuhan Cirebon.

1. Hubungan $(1-1) ;(1-24)$

Penampilan pemandu wisata (guide) dan staf menarik upaya teknisnya yaitu dengan penampilan dan pakaian yang rapih serta pelatihan karyawan, pemandu wisata, dan tenaga teknis lainnya.

2. Hubungan (2-2)

Papan petunjuk tempat atau arah dapat terlihat jelas hal yang perlu diperhatikan yaitu warna dan tulisan di papan petunjuk dibuat dengan jelas.

3. Hubungan (3-4); (3-5);(3-8);(3-12); (3-22)

Kebersihan lingkungan luar maupun dalam perlu diatasi dengan tersedianya tempat sampah, tersedianya peralatan kebersihan, tanaman yang terawat dan rumput dipotong rapi, tenaga kebersihan yang memadai serta keteraturan pedagang kaki limu ikut memberikan kontribusi.

4. Hubungan (4-3); (4-6)

Tempat parkir yang memadai diperlukan area parkir yang luas, dapat dilakukan dengan melakukan renovasi dan restorasi.

5. Hubungan (5-4); (5-5)

Tersedianya sarana kebersihan dapat diwujudkan dengan tersedia tempat sampah dan tersedia peralatan kebersihan.

6. Hubungan (6-4);(6-5);(6-6);(6-12)

Toilet yang bersih dan nyaman dapat diatasi melalui tersedianya tempat sampah, tersedianya peralatan kebersihan, melakukan renovasi dan restorasi, serta tenaga kebersihan yang memadai dari sisi jumlah personil.

7. Hubungan (7-6); (7-7); (7-10)

Bangunan dan benda-benda bersejarah terawat dan terjaga keotentikannya dapat diatasi melalui renovasi dan restorasi yang didukung juga oleh pemerintah dan perlu juga bendabenda museum ditata dengan rapih.

8. Hubungan $(8-5) ;(8-8) ;(8-12)$

Taman terawat dan asri didukung dengan tersedianya peralatan kebersihan, tanaman terawat dan rumput dipotong dengan rapi serta tenaga kebersihan yang memadai dari sisi jumlah personil.

9. Hubungan (9-7) ; (9-9)

Koleksi museum yang bervariasi perlu dilengkapi koleksi museum atau ditambah serta dukungan dari pemerintah untuk dapat merealisasikannya.

10. Hubungan (10-6) ; (10-7) ; (10-9) ; (10-10)

Penataan benda-benda bersejarah berhubungan dengan benda-benda museum tertata dengan baik, renovasi dan restorasi, kelengkapan koleksi museum dan dukungan pemerintah yang baik.

11. Hubungan (11-11)

Tersedia toko souvenir dengan demikian perlu adanya toko souvenir resmi sehingga dapat memenuhi keinginan belanja oleh-oleh bagi pengunjung dengan nyaman.

12. Hubungan $(12-12) ;(12-22) ;(12-24)$

Kesiagaan petugas kebersihan dengan adanya tenaga kebersihan yang memadai, keteraturan pedagang kaki lima serta pelatihan karyawan, pelatihan karyawan, pemandu wisata dan tenaga teknis lainnya.

13. Hubungan (13-13); (13-24)

Kesiagaan petugas parkir berhubungan dengan kesiapan petugas parkir dengan pelatihan karyawan, pemandu wisata dan tenaga teknis lainnya.

14. Hubungan (14-14); (14-15); (14-24)

Kesiagaan petugas keamanan dengan tenaga keamanan yang memadai serta tersedianya kamera CCTV dan pelatihan karyawan, pemandu wisata dan tenaga teknis lainnya. 
15. Hubungan (15-7) ; (15-14);(15-15);(15-16)

Keamanan dan kenyamanan di sekitar area wisata dengan melalui penertiban (pungli), tenaga keamanan yang memadai, tersedianya kamera pengawas (CCTV) serta dukungan pemerintah.

16. Hubungan (16-14); (16-15) ; (16-16); (16-23)

Keamanan parkir kendaraan melalui penertiban (pungli), tenaga keamanan yang memadai, tersedianya kamera pengawas (CCTV) serta sosialisasi dan pendekatan kepada masyarkat sekitar.

17. Hubungan $(17-17) ;(17-18) ;(17-24)$

Kemampuan pemandu wisata menyampaikan informasi dengan baik melalui penguasaan materi presentasi (sejarah keraton), komunikasi dengan bahasa yang baik dan mudah dimengerti serta pelatihan rutin bagi karyawan, pemandu wisata dan tenaga teknis lainnya.

18. Hubungan (18-19); (18-20); (18-24)

Layanan pembelian tiket masuk yang mudah dan cepat melalui kesigapan petugas tiket dalam melayani, computer dan printer untuk cetak tiket terawat dengan baik serta pelatihan bagi karyawan, pemandu serta petugas teknis lainnya.

19. Hubungan (19-6) ; (19-7) ; (19-9) ; (19-10)

Sebagai sarana edukasi tentang sejarah dan budaya yang menarik dengan melengkapi koleksi museum, penataan benda-benda sejarah dengan baik, dukungan pemerintah yang baik serta renovasi dan restorasi.

20. Hubungan (20-21)

Harga tiket masuk yang terjangkau melalui pemberian diskon tiket masuk.

21. Hubungan $(21-4) ;(21-6) ;(21-7) ;(21-15) ;(21-22) ;(21-23)$

Penataan pedagang kaki lima melalui keteraturan pedagang kaki lima, sosialisasi dan pendekatan dengan warga sekitar, tersedianya tempat sampah, renovasi dan restorasi, serta penertiban atau pungli dan dukungan pemerintah.

22. Hubungan (22-7); (22-14); (22-15); (22-23)

Warga lingkungan sekitar ramah melalui sosialisasi dan pendekatan dengan warga lingkungan sekitar, penertiban jika ada pungli, tenaga keamanan yang memadai, serta dukungan dari pemerintah.

23. Hubungan (23-18); (23-24)

Staf dan pemandu menyambut pengunjung dengan ramah melalui komunikasi dengan bahasa yang baik dan mudah dimengerti serta melalui pelatihan bagi karyawan, pemandu dan staf teknis lainnya.

\section{e. Hubungan Antar Respon Teknis}

Pada bagian ini menerangkan hubungan antar respon teknis, sehingga dapat diidentifikasi keterkaitan teknis dari suatu fungsi kualitas. Terdapat 14 hubungan positif kuat dan 12 hubungan kuat. Semua hubungan tersebut secara keseluruhan dapat dilihat pada bagian atap Gambar 1.

\section{Pembahasan}

Berdasarkan pengukuran kualitas pelayanan yang dilakukan dengan metode SERVQUAL khususnya Gap 5 (gap pelanggan) yaitu pengukuran berdasarkan lima dimensi kualitas pelayanan (tangibles, reliability, assurance, responsiveness, emphaty) maka dapat diperoleh nilai kesenjangan atau gap dari setiap dimensi yang berarti dapat menunjukkan kualitas suatu layanan. Dari lima dimensi tersebut diatas, dapat diurutkan nilai kesenjangannya dari dimensi yang memiliki gap terbesar sampai terkecil.

Dimensi yang paling besar kesenjangannya yaitu dimensi responsiveness (peringkat gap kesatu). Nilai dimensi responsiveness sebesar -0.993 menunjukkan ketidakpuasan terhadap kualitas pelayanan yang antara lain: cepat tanggapnya petugas kebersihan, petugas parkir dan keamanan. Atribut kesiagaan petugas kebersihan memperoleh gap sebesar -1.155 memberikan kontribusi cukup besar terhadap gap dari dimensi responsiveness.

Dimensi assurance memiliki peringkat gap kedua dengan nilai sebesar -0.969. Dari kesenjangan (gap) tersebut menunjukkan bahwa pengunjung tidak puas terhadap pelayanan Keraton Kasepuhan Cirebon terhadap keamanan dan kenyamanan di area wisata serta keamanan parkir kendaraan. 
Dimensi tangible memiliki peringkat gap ketiga dengan nilai sebesar -0.818. Dari kesenjangan tersebut menunjukkan bahwa pengunjung tidak puas terhadap pelayanan Keraton Kasepuhan Cirebon dalam hal penampilan pemandu wisata (guide) dan staf, papan petunjuk yang kurang jelas, kebersihan lingkungan, tempat parkir kurang memadai, sarana kebersihan, toilet umum, bangunan dan benda-benda yang dipamerkan, taman, koleksi museum, penaatan benda-benda di museum, serta tidak adanya toko souvenir resmi. Atribut yang paling mempengaruhi terhadap dimensi ini yaitu kebersihan lingkungan (indoor \& outdoor), tersedia sarana kebersihan dan toilet yang bersih dan nyaman serta taman terawat dan asri.

Dimensi reliability memiliki peringkat gap keempat dengan nilai sebesar -0.679. Dari kesenjangan tersebut menunjukkan bahwa pengunjung tidak puas terhadap pelayanan Keraton Kasepuhan Cirebon dalam hal kemampuan pemandu wisata menyampaikan informasi, layanan pembelian tiket, sebagai sarana edukasi yang menarik, harga tiket, penataan pedagang kaki lima. Dari dimensi reliability diatas, atribut yang paling besar kesenjangannya adalah penataan pedagang kaki lima dengan nilai sebesar -1.098. Penataan pedagang kaki lima bagi pengunjung dipersepsikan sebagai atribut yang paling menjadi perhatian dan menjadi kontribuasi yang besar akan ketidakpuasan terhadap dimensi reliability.

Dimensi emphaty memiliki peringkat gap kelima atau dimensi yang memperoleh gap yang paling kecil dengan nilai sebesar -0.539. Dari kesenjangan tersebut menunjukkan bahwa pengunjung tidak puas terhadap pelayanan Keraton Kasepuhan Cirebon dalam hal keramahan warga lingkungan sekitar serta penyambutan pengunjung dengan baik. Dimensi ini menunjukkan kepekaan atau perasaan baik dari penyelenggara layanan dalam hal ini Keraton Kasepuhan Cirebon maupun lingkungan sekitarnya.

Selain dari kelima dimensi tersebut diatas, secara keseluruhan diperoleh skor SERVQUAL tunggal atau kesenjangan total dari semua atribut kebutuhan pelanggan yaitu sebesar -0.80 . Dengan demikian dari penilaian tersebut diatas, secara keselurahan pelayanan di Keraton Kasepuhan Cirebon perlu dilakukan perbaikan karena menurut persepsi yang dirasakan pengunjung dengan apa yang diharapkan masih terdapat kesenjangan.

Penilaian pengunjung terhadap kualitas pelayanan yang diberikan memunculkan kebutuhankebutuhan dengan tingkat kepentingan yang berbeda-beda begitu pula dengan kualitas yang dirasakan. Dari hasil perhitungan nilai SERVQUAL dan menemukan fakta bahwa nilai kualitas yang dibutuhkan pengunjung masih belum puas dan dianggap penting untuk ditindaklanjuti dan dilakukan upaya perbaikan. Setelah ditelusuri dan dikembangkan lebih lanjut dengan metode Quality Function Deployment (QFD) bagaimana hubungan antara respon teknik dengan kebutuhan pelanggan yang dirancang dalam rumah kualitas (House of Quality) dengan berbagai perhitungan yang dimasukkan dalam matriks perencanaan.

Berdasarkan perhitungan prioritas perbaikan kualitas pelayanan wisata di Keraton Kasepuhan Cirebon yang perlu dilakukan berdasarkan sepuluh peringkat teratas dengan nilai bobot relatif paling besar adalah:

1. Perlu adanya tenaga kebersihan (bobot relatif 7.9) yang memadai sehingga kebersihan dapat menjadi perhatian yang lebih, mengingat dari hasil observasi dan wawancara masalah kebersihan adalah masalah yang paling utama dikeluhkan pengunjung. Upaya perbaikannya seperti melakukan perekrutan tenaga kebersihan tetap yang nantinya diharapkan dapat menjaga kebersihan area wisata dengan baik. Menurut pihak keraton tenaga kebersihan merupakan sukarelawan yang mengabdi pada Sultan.

2. Dari hasil observasi di area wisata begitu mudahnya orang-orang tertentu keluar masuk area wisata serta melakukan pungutan atau bahasa yang digunakan untuk sedekah. Penertiban adalah sebagai solusi perbaikannya (bobot relatif 7.9). Dengan penertiban ini maka akan menjawab kebutuhan pelanggan berupa keamanan dan kenyamanan berwisata, keamanan kendaraan, serta menertibkan pedagang kaki lima serta menertibkan warga sekitar yang kurang menghargai pengunjung. 


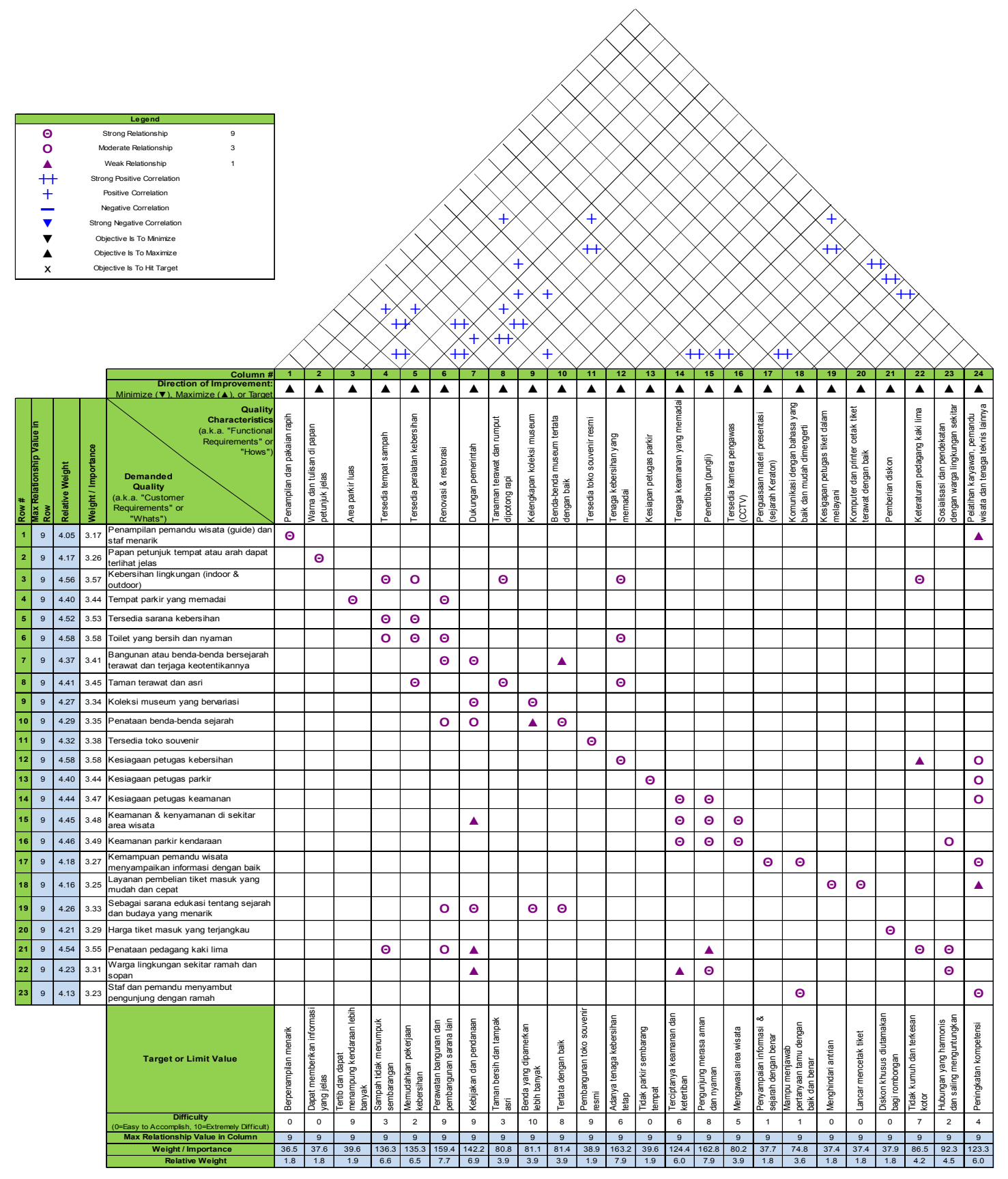

Gambar 1. House of Quality Keraton Kasepuhan Cirebon

3. Meningkatkan renovasi dan restorasi (bobot relatif 7.7), aspek ini perbaikan yang harus dilakukan antara lain: perluasan tempat parkir, perbaikan toilet umum serta memberikan tempat khusus bagi para pedagang kaki lima. Renovasi dan restorasi yang paling utama adalah pada bagian bangunan dan benda-benda yang dipamerkan di museum agar tampak lebih segar serta tidak terkesan tua. Perlu penataan yang baik benda-benda yang dipamerkan juga diperlukan sehingga tampak lebih menarik. Dan untuk menjawab kebutuhan pelanggan (pengunjung) sebagai sarana edukasi tentang sejarah dan budaya yang menarik bisa dilakukan dengan cara mengadakan atraksi berupa tarian saat pengunjung tiba terutama bagi pengunjung yang datang bersama rombongan dan cukup dilakukan pada hari libur saja. Selain itu juga dengan melakukan pembangunan galeri seni seperti galeri batik sehingga sambil berwisata pengunjung 
juga dapat pengetahuan tambahan membatik. Hal lainnya aspek teknis yang perlu dilakukan perbaikan adalah pedagang kaki lima.

4. Perlu peningkatan dukungan dari pemerintah (bobot relatif 6.9) baik di tingkat pusat maupun daerah. Dukungan pemerintah dalam peningkatan atau perbaikan kualitas layanan Keraton Kasepuhan sangat dibutuhkan terutama pada bagian inti dari obyek wisata yaitu bangunan serta benda-benda sejarah yang dipamerkan. Dukungan dari pemerintah tersebut berupa kebijakan sekaligus pendanaan. Renovasi dan restorasi yang disebutkan diatas membutuhkan biaya yang besar sehingga campur tangan pemerintah sangat dibutuhkan. Dari sisi koleksi benda-benda juga pemerintah diharapkan dapat membantu dengan melakukan duplikasi atau tiruan bendabenda sejarah yang ada sehingga walaupun benda aslinya tidak ada. Penataan pedagang kaki lima juga membutuhkan peranan pemerintah, hal ini bisa dilakukan dengan cara pembinaan melalui dinas koperasi dan usaha kecil \& menengah. Untuk menjawab kebutuhan pelanggan berupa keamanan dan kenyamanan di area wisata Keraton Kasepuhan peran pemerintah perlu dilibatkan antara lain memberikan dukungan keamanan untuk mengerahkan kepolisian terutama polisi khusus wisata agar terciptanya kenyamanan dan keamanan berwisata. Sosialisasi dan pengarahan pada warga lingkungan sekitar Keraton bahwa pentingnya menjaga ketertiban serta norma-norma kesopanan terhadap tamu yang berkunjung serta menanamkan pentingnya arti wisata bagi pembangunan serta peningkatan ekonomi masyarakat.

5. Ketersediaan tempat sampah (bobot relatif 6.6) sebagai jawaban dari kebutuhan pelanggan yaitu kebersihan lingkungan (indoor \& outdoor), tersedianya sarana kebersihan, toilet yang bersih dan nyaman serta penataan pedagang kaki lima. Pihak manajemen Keraton Kasepuhan perlu melakukan pengadaan tempat sampah sehingga mendukung kebersihan lingkungan serta kemudahan sarana kebersihan. Penempatan tempat sampah di titik strategis di lingkungan keraton dan di dalam toilet.

6. Ketersediaan peralatan kebersihan (bobot relatif 6.5) untuk menjawab kebutuhan pelanggan akan kebersihan lingkungan, tersedianya sarana kebersihan, toilet yang bersih dan nyaman, serta taman yang terawat dan asri. Peralatan kebersihan ini antara lain tersedianya sabun pencuci tangan di toilet serta gayung dalam kondisi baik atau jangan sampai tidak tersedia. Kenyamanan di toilet dapat diatasi antara lain dengan tersedianya pengharum ruangan sehingga di dalam toilet tidak bau.

7. Tenaga keamanan yang memadai (bobot relatif 6.0) menjadi jawaban kebutuhan pelanggan akan keamanan dan kenyamanan di sekitar area wisata, keamanan kendaraan di tempat parkir serta menjadi jawaban akan kesiagaan petugas keamanan saat dibutuhkan. Tenaga keamanan yang dimiliki sebanyak dua orang dengan bergantian shift atau hari kerja. Petugas keamanan hanya berjaga didepan pintu gerbang masuk saja tidak ada petugas yang menjaga di area lainnya. Dengan jumlah tenaga keamanan yang memadai juga diharapkan kesiagaan akan keamanan dan ketertiban di area wisata dapat terjaga seperti warga sekitar yang berbuat ulah.

8. Perlunya dukungan dari manajemen berupa pelatihan (bobot relatif 6.0) untuk meningkatkan kompetensi semua karyawan untuk menjawab kebutuhan pelanggan agar penampilan pemandu wisata dan staf menarik apakah itu dari fisik maupun pakaian yang dikenakan. Untuk pakaian perlu pengadaan serta secara regular diganti sehingga tidak terkesan kusam. Petugas kebersihan, petugas parkir dan kesiagaan petugas keamanan agar sigap dan selalu siap dalam menyelesaikan tugasnya. Dengan adanya pelatihan maka kemampuan dapat ditingkatkan dalam menyampaikan informasi bagi para pemandu. Meningkatkan cara berkomunikasi yang baik mengingat pengunjung memiliki latar belakang pendidikan yang berbeda-beda. Disamping itu pula melalui pelatihan dapat memotivasi para pekerja pariwisata untuk tetap selalu semangat dalam melayani tamu dengan menyambut pengunjung penuh keramahan serta bersikap selalu ingin membantu.

9. Sosialisasi dan pendekatan dengan warga lingkungan sekitar (bobot relatif 4.5) sebagai jawaban dari kebutuhan pelanggan yaitu mengenai keamanan parkir kendaraan, penataan pedagang kaki lima serta keberadaan warga lingkungan sekitar. Dengan adanya sosialisasi tersebut maka mengikutkan warga sekitar untuk menjaga keamanan, dan apabila berdagang harus menjaga kesopanan.

10.Prioritas perbaikan kesepuluh ini berupa keteraturan pedagang kaki lima (bobot relatif 4.2) hal ini untuk mengkondisikan agar kebersihan dapat terjaga, sehingga walau terbatasnya tenaga 
kebersihan masih bisa diatasi kebersihan lingkungan dan pedagang kaki lima tertata dengan baik tidak terlihat kumuh atau kotor.

\section{KESIMPULAN}

1. Hasil penelitian menemukan bahwa terdapat kesenjangan antara harapan dan persepsi kualitas pelayanan yang dirasakan pelanggan internal. Dari lima dimensi kualitas pelayanan (service quality) faktor yang paling mempengaruhi kualitas pelayanan dengan kesenjangan paling besar secara berturut-turut adalah daya tanggap (responsiveness); Jaminan (assurance); penampilan (tangibles); kehandalan (reliability); dan empati (emphaty).

2. Dari keluaran Quality Function Deployment dapat dibuat usulan program peningkatan kualitas pelayanan public kepariwisataan obyek wisata Keraton Kasepuhan Cirebon, yaitu:

a. Pembenahan Sistem Operasional

Program pembenahan sistem operasional ini berupa pemberlakuan sistem yang lebih baik serta terstandar. Dengan demikian dibutuhkan pembuatan prosedur pelayanan terstandar, adanya job desk yang jelas bagi setiap karyawan, standar harga, standar keamanan, jadwal kerja serta pembuatan papan peringatan bagi wisatawan.

b. Perbaikan dan Penambahan Fasilitas

Program ini dilakukan untuk memenuhi keinginan pengunjung terhadap kelengkapan sarana. Program perbaikan fasilitas dilakukan terhadap fasilitas/sarana kepariwisataan yang diperkirakan masih dapat berfungsi jika diperbaiki sedangkan program penambahan fasilitas dilakukan jika pada kenyataannya fasilitas yang dibutuhkan benar-benar tidak ada sedangkan kebutuhan terhadap fasilitas tersebut sangat dibutuhkan. Program ini bisa berupa pembangunan galeri serta toko souvenir resmi, perbaikan tempat parkir, sarana kebersihan.

c. Penambahan Sumber Daya Manusia

Program usulan ini bertujuan untuk melengkapi personil yang sudah ada terutama dalam hal kebersihan, keamanan serta tenaga yang memahami mengenai museum atau benda-benda sejarah.

\section{d. Pelatihan}

Program usulan pelatihan ini bertujuan untuk meningkatkan kualitas sumber daya manusia yang terlibat langsung dalam memberikan pelayanan kepada wisatawan. Program pelatihan ini dapat dibagi pelatihan teknis atau praktek lapangan. Sehingga dapat ditingkatkan kemampuan serta kompetensi dari petugas. Pelatihan kepribadian harus diberikan untuk meningkatkan kedisiplinan, tanggung jawab terhadap pekerjaan serta mampu menghadapi wisatawan yang berbagai macam sifat. Pelatihan pemahaman perangkat pendukung kegiatan operasional seperti prosedur pelayanan standar, job description atau sistem informasi kepariwisataan.

3. Disarankan agar penelitian selanjutnya bukan hanya wisatawan domestik saja yang diteliti tetapi juga wisatawan mancanegara serta dapat melanjutkan pada HOQ fase berikutnya.

\section{DAFTAR PUSTAKA}

Cohen, L., \& Cohen, L. (1995). Quality function deployment: how to make QFD work for you. Reading, MA: Addison-Wesley.

Markovic, S., Raspor Jankovic, S., \& Komšić, J. (2013). Museum Service Quality Measurement Using the Histoqual Model (SSRN Scholarly Paper No. ID 2289769). Rochester, NY: Social Science Research Network. 
Parasuraman, A., Zeithaml, V. A., \& Berry, L. L. (1985). A Conceptual Model of Service Quality and Its Implications for Future Research. Journal of Marketing, 49(4), 41.

Parasuraman, A., Zeithaml, V. A., \& Berry, L. L. (1988). Servqual. Journal of retailing, 64(1), $12-$ 40.

Parasuraman, A., Zeithaml, V. A., \& Berry, L. L. (1990). Delivering quality service: Balancing customer perceptions and expectations. Simon and Schuster.

Pawitra, T. A., \& Tan, K. C. (2001). Integrating SERVQUAL and Kano's Model Into QFD for Service Excellence Development. Managing Service Quality: An International Journal, 11(6), 418-430.

Pawitra, T. A., \& Tan, K. C. (2003). Tourist satisfaction in Singapore-a perspective from Indonesian tourists. Managing Service Quality: An International Journal, 13(5), 399-411.

Shi, H. Y., \& Chen, C. C. (2008). A Study of Service Quality and Satisfaction for Museums-Taking the National Museum of Prehistory as an Example.

Triwibowo, S., Rukmi, H. S., \& Harsono, A. (2014). Usulan Peningkatan Kualitas Pelayanan Pada Kawasan Wisata Kawah Putih Perum Perhutani Jawa Barat dan Banten dengan menggunakan Metode Service Quality (SERVQUAL). RekA Integra, 2(1).

Wijaya, T. (2011). Manajemen Kualitas Jasa (Desain Servqual, QFD, dan Kano Disertai Contoh Aplikasi dalam Kasus Penelitian). PT Indeks Jakarta.

Yuri, T., \& Nurcahyo, R. (2013). TQM Manajemen Kualitas Total dalam Perspektif Teknik Industri. PT Indeks Jakarta. 